\title{
COLONY STRENGTH AND QUEEN REPLACEMENT IN Melipona marginata (APIDAE: MELIPONINI)
}

\author{
KLEINERT, A. DE M. P. \\ Departamento de Ecologia, Instituto de Biociências, Universidade de São Paulo, \\ CEP 05508-900, São Paulo, Brazil \\ Correspondence to: Astrid de M. P. Kleinert, Universidade de São Paulo, Instituto de Biociências, \\ Departamento de Ecologia, Rua do Matão, travessa 14, CEP 05508-900, \\ São Paulo, SP, e-mail: astridk1@ib.usp.br \\ Received October 8, 2003 - Accepted November 13, 2003 - Distributed August 31, 2005
}

\begin{abstract}
Physogastric queens of Melipona marginata were removed from their colonies in order to verify the acceptance of a new queen by workers. Colony strength was evaluated according to queen oviposition rate and comb diameters. Replacement was observed seven times. Its occurrence and speed related positively to colony strength, independently of queen's age. In weak colonies, queen replacement was observed only once, following colony population increase that occurred after introduction of combs from another colony. Worker oviposition after queen removal was observed three times: in a strong colony with virgin queens and males, and in two of the weak colonies. In the first two or three days of new queen oviposition, during which most of the eggs were eaten by the queen, worker oviposition preceded almost all provisioning and oviposition processes (POPs). After this period, worker oviposition decreased until it reached around 25\% of the POPs. Daily oviposition rate of young queens decreased or was even interrupted by hatching of their first brood.
\end{abstract}

Key words: stingless bees, queen replacement, worker oviposition, colony strength, Melipona.

\section{RESUMO}

\section{Condições da colônia e substituição de rainhas em Melipona marginata (Apidae: Meliponini)}

Rainhas fisogástricas de Melipona marginata foram removidas de suas colônias para verificar a aceitação de uma nova rainha pelas operárias. O estado da colônia foi avaliado de acordo com a taxa de oviposição da rainha e o diâmetro dos favos. Em sete dos casos, foi observada a substituição das rainhas, cuja ocorrência e velocidade estiveram relacionadas positivamente ao estado da colônia, independente da idade da rainha. Em colônias fracas, a substituição da rainha foi observada uma única vez, depois que a população da colônia aumentou, após a introdução de favos de cria de outra colônia. Após a remoção da rainha, a oviposição de operárias foi observada três vezes: em uma colônia forte, com rainhas virgens e machos, e em duas das colônias fracas. Nos primeiros dois ou três dias após o início da oviposição pela nova rainha, em quase todos os processos de aprovisionamento e postura (POPs), suas posturas eram precedidas pela oviposição de operárias (sendo a maior parte dos ovos comidos pela rainha), que diminuiu a partir daí até sua observação em cerca de $25 \%$ de todos os POPs. A taxa diária de oviposição de rainhas jovens decresceu ou foi interrompida com a eclosão de suas primeiras crias.

Palavras-chave: meliponíneos, substituição de rainhas, oviposição de operárias, condições da colônia, Melipona. 


\section{INTRODUCTION}

In most stingless bee species of the genus Melipona, the queen mates with only one male (Kerr et al., 1962; Silva et al., 1972; Contel \& Kerr, 1976; Peters et al., 1999; Strassmann, 2001), leading to a high degree of relatedness within female offspring.

By behavioral and/or pheromonal dominance mechanisms, queens in these species apparently ward off attempts by workers to obtain colony control. Male production is at the center of this reproductive divergence (Ratnieks, 1988; Crespi, 1992; Peters et al., 1999). Workers of these bees can lay eggs before and after queen oviposition. The former are generally eaten by the queen and for this reason are called trophic eggs. The latter are reproductive eggs from which males hatch (Beig, 1972; Bego, 1982; Beig et al., 1985; Sommeijer \& van Buren, 1992; Imperatriz-Fonseca \& Kleinert, 1998; Koedam et al., 1999). In Melipona marginata colonies, as in other Melipona species (Sommeijer et al., 1984; Chinh et al., 2003), worker oviposition before queen oviposition is a common event. However, its frequency varies (Kleinert-Giovannini, 1989). For some authors, the trophic eggs laid by workers in queenright colonies provide food, thus compensating for the rarity, as compared to Apis mellifera (Free, 1957), of direct food transfer between queens and workers (Sakagami \& Zucchi, 1968). Others consider oophagy, of which protein transfer is a consequence, as another sign of queen dominance (Sommeijer, 1985; Imperatriz-Fonseca \& Kleinert-Giovannini, 1987; Kleinert-Giovannini, 1989).

In the case of Melipona marginata, analysis of daily queen oviposition rates indicated the existence of queen productivity cycles (KleinertGiovannini, 1989). Besides environmental pressures, these cycles may be closely related to reproductive divergence between queen and workers and the maintenance of queen control. As in other Melipona, virgin queens are produced throughout the year and are usually killed soon after hatching (Silva et al., 1972; Imperatriz-Fonseca \& Zucchi, 1995). Sometimes they are kept for longer periods (Kleinert \& Imperatriz-Fonseca, 1994). This may also be linked to the queens' lifecycles, as they can even be found trying to participate in oviposition processes by climbing onto the comb under construction, which is the main territory of the mother queen.
This study tries to explain colony conditions related to queen replacement, in addition to investigating the kind of behaviors that could indicate an increase of worker-queen conflict.

\section{MATERIALS AND METHODS}

Eight colonies of Melipona marginata kept in observation hives were used: one belonging to the subspecies carioca (Mc3), one to marginata (Mm19), and the remainder to the subspecies obscurior (Mo).

After the physogastric queens were carefully removed from the colonies, observations were made of worker behavior and whether or not acceptance of a new queen occurred. In one of the weak colonies (Mo20), a comb (with 132 cells) from another colony (Mo21, in which workers and virgin queens were sisters of workers from Mo20) was introduced after 80 days of orphanhood. On the $149^{\text {th }}$ day, three more combs ( $\mathrm{T}=391$ cells: 279 from Mm19 and 112 from Mo18 (the latter not included in these experiments) with pupae (workers and virgin queens) were also introduced to see whether in this case a population increase would induce queen replacement.

Daily observations were carried out for one month in all colonies before queen removal. This was done through brood-cell mapping so as to evaluate queen oviposition rates. Also, behavioral notes on oviposition processes and worker-queen interactions were made, and presence or absence of virgin queens and males was recorded.

To verify the intensity and/or frequency of a given behavior, an arbitrary scale was elaborated, ranging from 0 (no behavioral alteration) to 2 (maximum intensity and/or frequency). The number of trophallaxes between queens and workers was recorded through 5-minute samplings; the mean number was related to the established scale $(n=0$ to $0 ; \mathrm{n}=4$ to $1 ; \mathrm{n}=8$ to 2 ).

Colony strength was evaluated according to the queen oviposition rate and the comb diameter (Table 1). Intermediate values indicated intermediate colony strength.

Precise queen age was known with respect to only two colonies. However, queens of stingless bees frequently vibrate their wings (with greater or lesser intensity depending upon the species), which because they fray over time can be used to approximate, at least 
comparatively, the age of the queen (see Table 2). However, in this species some variation in the speed of this process can be observed, depending on the kind of interactions with other members of the colony.

\section{RESULTS}

Queen-worker interactions

Four main types of interactions between queen and workers were observed:

1) Trophallaxis:

Virgin queens and physogastric queens were always the solicitors.

2) Antennal contacts:

In most interactions between both physogastric and virgin queens with workers, one animal touched with its antennae the upper part of the head of the other; this behavior was sometimes reciprocated.

3) Dominance and subordination behavior:

For either newly inseminated or physogastric queens, two kinds of interactions were regarded as expressing dominance relationships:

a) when the queen and a worker meet on the comb, the latter may offer its back to the former, who touches it with her front legs and antennae, sometimes partially climbing onto the worker's thorax; b) in the same type of meeting, the worker may lower itself completely, in which case the queen always climbs onto the worker's thorax.

4) Agonistic behavior:

a) workers attack the queen or virgin queen with open mandibles; they sometimes climb on her abdomen, which they try to bite it;

b) at other times this attack may become still fiercer and workers may try to sever the queen's or virgin queen's head, while other workers simultaneously pull and bite on her wings and legs;

c) another agonistic behavior is exhibited by workers in the presence of a physogastric queen or a newly inseminated queen, mainly during oviposition processes: some workers raise their abdomen, while spreading their wings (sometimes vibrating them) and opening their mandibles widely. They usually remain at least $1 \mathrm{~cm}$ away from the queen, which distinguishes this behavior from the first type mentioned, in which workers with open mandibles actually attack the queen. Other authors (e.g., Zucchi, 1993) have mentioned this kind of behavior while studying other species of Melipona. However, they considered it solely as a ventilation mechanism and, therefore, without aggressive intent.

TABLE 1

Colony strength.

\begin{tabular}{|c|c|c|}
\hline Strength & $\begin{array}{c}\text { Queen oviposition } \\
\text { (eggs/per day) }\end{array}$ & $\begin{array}{c}\text { Comb diameters } \\
\text { (cm) }\end{array}$ \\
\hline Strong & $>25$ & $7-12$ \\
\hline Medium & $10-20$ & $4-6$ \\
\hline Weak & $<8$ & $0-3$ \\
\hline
\end{tabular}

TABLE 2

Queens'age.

\begin{tabular}{|l|c|}
\hline \multicolumn{1}{|c|}{ Wing fray } & $\begin{array}{c}\text { Age } \\
\text { (in months) }\end{array}$ \\
\hline 0. No fraying & $0-8$ \\
\hline 1. Extremities slightly frayed & $9-17$ \\
\hline 2. At least 2/3 frayed & $18-24$ \\
\hline 3. Only stumps & more than 24 \\
\hline
\end{tabular}




\section{Induced replacement by queen removal}

Table 3 presents the results obtained from nine queen-removal experiments in eight different colonies. In Mo9, experimental removal was performed twice. Replacement was observed seven times. Its occurrence and speed were related to colony strength, independently of queen age (although none of the colonies presented very old queens). In weak colonies, queen replacement was observed once, after the colony population had been increased by comb introduction.
Only in strong colonies was conspicuous worker excitement observed after queen removal, and the only exception in weak colonies was Mo9/ $\mathrm{b}$, where in the queen's final days many agonistic behaviors of workers toward her were noted (degree 2 ), mainly during oviposition processes. Some workers tried to bite her, after which the queen initiated trophallactic contacts (degree 2) with other workers on the comb, including those who were provisioning cells. In medium-strong colony Mo21, worker excitement reached degree 1.

TABLE 3

Colony responses after queen removal.

\begin{tabular}{|c|c|c|c|c|c|c|}
\hline \multicolumn{3}{|c|}{ Before removal } & \multicolumn{4}{|c|}{ After removal } \\
\hline $\begin{array}{c}\text { Colony } \\
\text { number and } \\
\text { strength }\end{array}$ & Queen age & $\begin{array}{l}\text { Mean daily } \\
\text { oviposition } \\
\text { rate }\end{array}$ & $\begin{array}{c}\text { Worker } \\
\text { excitement } \\
\text { after } \\
\text { removal }\end{array}$ & $\begin{array}{c}\text { Worker } \\
\text { oviposition }\end{array}$ & Replacement & $\begin{array}{c}\text { First } \\
\text { oviposit } \\
\text { on day }\end{array}$ \\
\hline $\begin{array}{c}\text { Mo9/a } \\
\text { strong } \\
\text { with males } \\
\text { and vq }\end{array}$ & $\mathrm{RC}$ (w.f. = 1) & $27.0 \pm 4.0$ & 2 (during $3 \mathrm{~h}$ ) & $4^{\text {th }}-12^{\text {th }}$ day & $\begin{array}{c}\text { Yes } \\
13^{\text {th }} \text { day after } \\
\text { removal: newly } \\
\text { inseminated } \\
\text { queen }\end{array}$ & $28^{\text {th }}$ \\
\hline $\begin{array}{l}\text { Mo16 } \\
\text { strong }\end{array}$ & $\mathrm{RF}=7.5$ months old & $28.0 \pm 4.0$ & 2 & No & Yes & $30^{\text {th }}$ \\
\hline $\begin{array}{l}\text { Mo21 } \\
\text { medium- } \\
\text { strong }\end{array}$ & RU (w.f. = 2) & $21.0 \pm 3.0$ & 1 & No & Yes & $13^{\text {th }}$ \\
\hline $\begin{array}{l}\text { Mo23 } \\
\text { medium }\end{array}$ & $\mathrm{RI}$ (w.f. = 1) & $12.0 \pm 3.0$ & 0 & No & Yes & $11^{\text {th }}$ \\
\hline $\begin{array}{l}\text { Mm19 } \\
\text { medium }\end{array}$ & RMA (w.f. = 2) & $15.6 \pm 6.0$ & 0 & No & Yes & $11^{\text {th }}$ \\
\hline $\begin{array}{c}\text { Mo17 } \\
\text { medium }\end{array}$ & $\mathrm{RR}$ (w.f. $=2-3$ ) & $12.0 \pm 3.0$ & 0 & No & Yes & $11^{\text {th }}$ \\
\hline $\begin{array}{l}\text { Mc3 } \\
\text { weak }\end{array}$ & RZ (w.f. $=0$ ) & $7.5 \pm 2.1$ & 0 & $\begin{array}{c}\text { Yes } \\
\text { Very irregular }\end{array}$ & No & - \\
\hline $\begin{array}{l}\text { Mo20 } \\
\text { weak }\end{array}$ & RU (w.f. = 2) & $\begin{array}{c}0 \\
\text { from } 10 \text { days } \\
\text { before } \\
\text { removal }\end{array}$ & 0 & $\begin{array}{l}\text { Yes } \\
\text { From } 68^{\text {th }} \text { day } \\
\text { after removal }\end{array}$ & $\begin{array}{l}\text { Yes } \\
\text { After combs } \\
\text { introduction on } \\
\text { the } 149^{\text {th }} \text { day }\end{array}$ & $176^{\text {th }}$ \\
\hline $\begin{array}{l}\text { Mo9/b } \\
\text { weak }\end{array}$ & $\begin{array}{c}\text { RD } \\
10 \text { months old }\end{array}$ & $5.9 \pm 2.6$ & 2 & No & No & - \\
\hline
\end{tabular}

(w.f. = wing fraying; capital letters = physogastric queen). 
Worker oviposition after queen removal was observed three times: in the strong colony (Mo9/ a) with virgin queens and males, and in two of the weak colonies (Mc3, Mo20). In colony Mc3 worker oviposition was observed once on the $15^{\text {th }}$ day after removal; this occurred together with the appearance of a virgin queen with distended abdomen. Next day the cell was opened and its content ingested. Workers attacked all hatched virgin queens. On the $30^{\text {th }}$ day after removal, workers began cell construction and oviposition, but all cells were soon opened and their contents ingested. In colony Mo20 workers began to oviposit 68 days after orphanhood. The process was interrupted for a while after the introduction of a comb (with 132 cells) on the $80^{\text {th }}$ day, and after the introduction of 3 combs (with 391 cells) on the $149^{\text {th }}$ day. Oviposition continued until the appearance of a virgin queen with a distended abdomen on the $167^{\text {th }}$ day.

First new-queen oviposition (always preceded by oophagy of workers' eggs) occurred later in strong colonies than it did in medium ones. On the first day of the newly inseminated queen $\left(13^{\text {th }}\right.$ day $)$ many trophallactic contacts (degree 2 ) between queen and workers and among workers were observed in colony Mo9/a, in which virgin queens and males were present at the time of removal. Agonistic behaviors of workers toward the new queen were also observed, and some even tried to bite her. The period till the first queen oviposition was characterized by continuous aggressive manifestations. During the five days after first oviposition, trophallaxis and antennal contacts were relatively frequent (degree 1), but no further aggressive behavior was observed.

The strong colony Mo16 contained no emerged virgin queens and males when the queen was removed. During the first 2 months, once the new queen started ovipositing, workers removed all larval food from some cells and adopted an agonistic posture during queen oviposition (with abdomen raised and mandibles widely opened). These acts were relatively frequent (degree 1 ). In the third month, when these behaviors were much less frequent, oviposition rate increased, becoming much more regular and occurring on a daily basis.
In medium and medium-strong colonies the first oviposition by the new queen was observed between the $11^{\text {th }}$ and $13^{\text {th }}$ day after removal. In these colonies no agonistic behavior toward the new queens was observed. In the medium-strong colony Mo21, ten days after the beginning of oviposition the newly fertilized queen was observed defecating on the upper comb, her feces readily being eaten by workers (normally, stingless bees queens defecate on the detritus deposit or on the colony floor).

The following remarks apply to all colonies observed:

With the appearance of virgin queens walking freely through the colony, a decrease in queen oviposition rate was found, sometimes preceded by an abrupt increase. The same was observed in orphan colonies with worker oviposition, once a virgin queen appeared with a distended abdomen.

With queen removal, cell construction was interrupted for at least 3 days in all colonies, and in the medium-strong colony Mm19 workers even destroyed operculated cells.

During the period between the appearance of the first new queen (sometimes just a virgin with a distended abdomen) and the first oviposition, an increase in the frequency and the intensity of trophallaxis and antennal contacts with workers was observed.

When attacked by workers, the newly inseminated queen sought trophallaxis with workers on the combs. The opposite was also observed: while maintaining trophallaxis with some of the workers, the queen was attacked by others. This occurred in the days before oviposition commenced.

In almost all POP instances, worker oviposition preceded queen oviposition during the initial 2 or 3 days of egg laying by the queen, who ate most of the workers' eggs. Afterwards, the frequency of workers' egg-laying decreased until it represented only $25 \%$ of POPs.

In all cases, with the emergence of the first brood either the daily oviposition rate of newly fertilized queens decreased or oviposition was completely interrupted. 


\section{DISCUSSION}

I have shown that in Melipona marginata some kind of reproductive-interest conflict occurs. To begin with, the queen maintains control over workers by behavioral and probably also by pheromonal means. Workers submit to her until some factor changes, whereafter the queen begins to lose control of the colony.

When virgin queens begin to walk freely through the colony without being threatened by workers, the high intensity of different pheromones inside the colony probably disturbs the workers. [Engels (1987) has demonstrated for Scaptotrigona postica that the main component of pheromone differs between virgin and physogastric queens.] This disturbance is indicated by the decrease in the queen's oviposition rate due to the decline in cell construction by workers. The abrupt oviposition increment observed just before its decline might be due to an attempt by the queen to recruit workers. Workers are distracted from their usual tasks and their attention strays to the virgins, thus endangering the queen with replacement. If she is still able to maintain control over workers, virgin queens are either killed or escape to swarm with some of the workers.

The situation just described may apply to worker oviposition in orphan colonies. When a virgin queen with a distended abdomen (indicating acceptance by some of the workers) arrives to a comb under construction, more competitive workers that are ovipositing suddenly increase both cell construction and oviposition rate. But if a virgin has already disturbed the colony, oviposition declines.

For Melipona marginata, the queen's behavioral dominance is evident from (a) her positioning mainly over brood combs, which are her main territory; (b) oophagy of worker eggs; and (c) the dominance-subordination mechanisms previously mentioned. The high frequency of worker oviposition in the first three days following insemination of the new queen and before her oviposition probably signals contestation. Oophagy by the queen emphasizes her dominance, and subsequent decline in worker oviposition evidences increasing queen control.

On the other hand, when the queen's control is not so effective, workers attempt to escape it. An agonistic behavior increase indicates contestation of her dominance. Another sign of the same thing is larval food removal from already provisioned cells, as observed in colony Mo16 during the new queen's first two months.

Trophallaxis between queen and workers probably constitutes a communication and recognition mechanism, and is more frequent when queens are either losing or establishing their dominance. Evidence supporting this hypothesis was supplied by the attack, by some workers in colony Mo9/a on a newly inseminated but not yet ovipositing queen, when trophallactic contacts were occurring between the new queen and other workers. The opposite was also verified in the same colony ten months later (Mo9/b) when the queen was attacked by some of the workers just before her removal. After this, she initiated trophallaxis with other workers on the comb.

Although effective food transfer may occur, as observed for Melipona marginata (KleinertGiovannini, 1989), pheromonal transfer is less likely because virgin or physogastric queens are the first to initiate solicitations. [As Velthuis (1972) pointed out, if trophallaxis were involved in this transmission, the inverse would be expected, with queens offering food to workers.] In these transfers, antennal contacts may be involved, which was the case in most interactions between queen and workers in the species studied here. Their higher frequency of these contacts was positively related to the higher trophallaxis frequency, principally when queens were either losing or establishing their dominance.

With respect to pheromonal transmission, it may be contributed to by abdomenal massage. In this work, abdomen massaging by the queen was more frequent during the time between first new queen oviposition and the first few days of ovipositing. It was generally preceded by trophallaxis with workers, as observed for Plebeia remota by Imperatriz-Fonseca et al. (1975). [As shown by several authors (Cruz-Landim et al., 1980; Mota, 1983, 1988) besides mandibular glands, tergal glands are also an important source of the stingless bees queen's pheromones.]

It is likely that pheromonal transmission also occurs via the queen's feces. A newly fertilized queen (Mo21) released feces within the first month of oviposition; feces were then eaten by workers. In 
other colonies of Melipona marginata, newly fertilized queens were observed releasing feces during the first days of oviposition, as were virgin queens with distended abdomens (KleinertGiovannini, 1989). In these contexts, feces release seems to be directly linked to dominance establishment, at a time when a positive pheromonal budget is decisive.

Queen dominance is most frequently attested to by workers behaving as if trying to escape, or otherwise rebelling against, the queen's control. In queenright colonies, such behavior signifies conflict between the queen and workers. Pheromonal activity could be an important factor in the queens' control over workers, but it remains to be proved. Among the specific questions awaiting answers are how this mechanism functions, and how the differences observed following queen's removal among colonies of different strengths can be explained.

In the present study, different kinds of behavior attached to queen-worker conflict have been cited that are based on observations of natural or induced queen supersedure. It was observed in both strong and medium colonies that a relatively larger number of workers restricts reproductive competition when these bees are working on brood combs. It was also found that workers not involved in reproduction accept a new queen more readily. But from this point on, the supersedure process depends on the pheromonal action of the new queen.

In weak colonies with few workers, almost all workers remained on the combs after queen removal, and very few individuals took over the other tasks of the colony. Reproductive competition was established among the few individuals who were almost exclusively occupied with brood combs. Opening of cells with eggs from other workers and ingestion of their contents was quite frequent, as were attacks on all hatching virgin queens. In this work, queen replacement was observed in these weak colonies only after the hatching of many individuals (391) introduced as pupae. A smaller comb (with 132 cells) introduced before this did not increase colony population to a level allowing virgin queens to be accepted by other workers. A minimum number of workers are clearly needed to begin worker oviposition just after queen removal or death.

When all replacement process steps have been taken, and a new queen begins to oviposit, she may have to face another attempt by workers to contest her dominance. This happens because it is advantageous for workers to rear their sisters, but as one of them supersedes the mother and becomes the new queen, rearing of this new queen brood is no longer advantageous. The hatching of the new queen's first brood therefore entails a confrontation between queen and workers, which is marked by a decrease in queen oviposition rate. Perhaps some kin recognition mechanisms are involved, making workers able to recognize their nieces as such. If the queen succeeds in establishing dominance over the workers, oviposition increases again. Once the conflict is resolved, the new queen's brood will gradually replace the older workers. An increase in colony population by introduction of combs from another colony just before the conflict facilitates a successful outcome by the queen, as observed in this study (colony Mc1). This may be due to the presence of genetically different individuals in the colony, which probably reduces the workers' ability to take advantage of kin recognition cues and allows the queen to achieve dominance, as noted for Apis by Hogendoorn \& Velthuis (1988).

Acknowledgement - Part of this work was supported by a grant from Fundação de Amparo à Pesquisa do Estado de São Paulo (FAPESP; Proc. 84/1655-6).

\section{REFERENCES}

BEIG, D., 1972, The production of males in queen-right colonies of Trigona (Scaptotrigona) postica. J. Apic. Res., 11(1): 33-39

BEIG, D., BUENO, O. C. \& MÜlleR, T. J., 1985, Características dos alvéolos de cria e postura de operárias em Melipona quadrifasciata anthidioides Lep. (Hym., Apidae, Meliponinae). Naturalia, 10: 75-81.

BEGO, L. R., 1982, On social regulation in Nannotrigona (Scaptotrigona) postica Latreille, with special reference to male production cycles (Hym., Apidae, Meliponinae). Bolm. Univ. São Paulo, 7: 181-196.

CHINH, T. X., GROB, G. B. J., MEEUWSEN, F. J. A. J. \& SOMMEIJER, M. J., 2003, Patterns of male production in the stingless bee Melipona favosa (Apidae, Meliponini). Apidologie, 34: 161-170.

CONTEL, E. P. B. \& KERR, W. E., 1976, Origin of males in Melipona subnitida estimated from data of an isozymic polymorphic system. Genetica, 46: 271-277.

CRESPI, B. J., 1992, Cannibalism and trophic eggs in subsocial and eusocial insects. In: M. A. Elgar \& B. J. Crespi (eds.), Cannibalism: ecology and evolution among diverse taxa. Oxford University Press, pp. 176-213. 
CRUZ-LANDIM, C., HÖFLING, M. C. A. \& IMPERATRIZFONSECA, V. L., 1980, Tergal and mandibular glands in queens of Paratrigona subnuda (Moure) (Hymenoptera: Apidae): morphology and associated behaviour. Naturalia, 5: 121-133.

ENGELS, W., 1987, Pheromones and reproduction in Brazilian stingless bees. Mem. Inst. Oswaldo Cruz, 82(III): 35-45.

FREE, J. B., 1957, The transmission of food between worker honeybees. British J. Anim. Behav., 5: 41-47.

HOGENDOORN, K. \& VELTHUIS, H. H. W., 1988, Influence of multiple mating on kin recognition by worker honeybees. Naturwiss., 75: 412-413.

IMPERATRIZ-FONSECA, V. L. \& KLEINERT-GIOVANNINI, A., 1987, The role of queens in stingless bees colonies. In. J. Eder \& H. Rembold (eds.), Chemistry and biology of social insects. München, Verlag J Peperney, pp. 708-709.

IMPERATRIZ-FONSECA, V. L. \& KLEINERT, A. de M. P., 1998, Worker reproduction in the stingless bee Friesella schrottkyi (Apidae, Meliponinae). Entomologia generalis, 23(3): 169-175.

IMPERATRIZ-FONSECA, V. L. \& ZUCCHI, R., 1995, Virgin queens in stingless bee (Apidae, Meliponinae) colonies: a review. Apidologie, 26: 231-244.

IMPERATRIZ-FONSECA, V., OLIVEIRA, M. A. C. \& IWAMA, S., 1975, Notas sobre o comportamento de rainhas virgens de Plebeia (Plebeia) remota Holmberg (Apidae, Meliponinae). Ciênc. \& Cult., 27(6): 665-669.

KERR, W. E., ZUCCHI, R., NAKADAIRA, J. T. \& BUTOLO, J. E., 1962, Reproduction in the social bees (Hymenoptera: Apidae). J. N. Y. Entomol. Soc., 70: 265-276.

KLEINERT-GIOVANNINI, A., 1989, Mecanismos de controle reprodutivo em Melipona marginata Lepeletier (Apidae, Meliponinae). Ph.D. Thesis, Instituto de Biociências, Universidade de São Paulo, São Paulo, Brazil, 145p.

KLEINERT, A. DE M. P. \& IMPERATRIZ-FONSECA, V. L., 1994, Virgin queen refuges in colonies of Melipona marginata (Apidae, Meliponinae). Rev. Brasil. Biol., 54(2): 247-251.

KOEDAM, D., CONTRERA, F. A. L. \& IMPERATRIZFONSECA, V. L., 1999, Clustered male production by workers in the stingless bee Melipona subnitida Ducke (Apidae, Meliponinae). Insectes Soc., 46: 387-391.

MOTA, M. H. V. B., 1983, Estudo comparativo das glândulas abdominais relacionadas com o comportamento social em Apidae (Apinae e Meliponinae). M.Sc. Dissertation, Instituto de Biociências, UNESP, Rio Claro, Brazil, 174p.
MOTA, M. H. V. B., 1988, Estudo comparativo das glândulas epidérmicas do abdômen dos meliponíneos (Hymenoptera, Apidae, Meliponinae). Ph.D. Thesis, Institute of Biosciences, UNESP, Rio Claro, Brazil, 170p.

PETERS, J. M., QUELLER, D. C., IMPERATRIZ-FONSECA, V. L., ROUBIK, D. W. \& STRASSMANN, J. E., 1999, Mate number, kin selection and social conflicts in stingless bees and honeybees. Proc. R. Soc. Lond., B 266: 379-384.

RATNIEKS, F. L. W., 1988, Reproductive harmony via mutual policing by workers in eusocial Hymenoptera. Am. Nat., 132: 217-236.

SAKAGAMI, S. F. \& ZUCCHI, R., 1968, Oviposition behavior of an Amazonic stingless bee, Trigona (Duckeola) ghiliani. J. Fac. Sci. Hokkaido Univ. Ser. VI, Zool., 16(4): 564-581.

SILVA, D. L. N., ZUCCHI, R. \& KERR, W. E., 1972, Biological and behavioural aspects of the reproduction in some species of Melipona (Hymenoptera, Apidae, Meliponinae). Anim. Behav., 20: 123-132.

SOMMEIJER, M. J., 1985, The social behavior of Melipona favosa F.: some aspects of the activity of the queen in the nest. J. Kansas Ent. Soc., 58(3): 386-396.

SOMMEIJER, M. J., DOHMEN, M. R. \& VAN ZEIJL, M., 1984, Morphological differences between worker-laid eggs from a queenright colony and a queenless colony of Melipona rufiventris paraensis (Hymenoptera, Apidae). Entomol. Ber., 44: $91-95$

SOMMEIJER, M. J. \& VAN BUREN, N. W. M., 1992, Male production by laying workers in queen right colonies of Melipona favosa (Apidae, Meliponinae). In: J. Billen (ed.), Biology and evolution of social insects. Leuven University Press, pp. 89-97.

STRASSMANN, J., 2001, The rarity of multiple mating by females in the social Hymenoptera. Insectes Soc., 48: 113.

VELTHUIS, H. H. W., 1972, Observations on the transmission of queen substances in the honey bee colony by the attendants of the queen. Behavior, 41(1-2): 105-129.

ZUCCHI, R., 1993, Ritualized dominance, evolution of queenworker interactions and related aspects in stingless bees (Hymenoptera: Apidae). In: T. Inoue \& S. Yamane (eds.), Evolution of insect societies. Hakuhinsha, Tokyo, pp. 207249 . 